study of the phenomena of immunity he appeared to be influenced more by Bordet than by the German school. It is recorded that Ehrlich referred to Bordet as "sein schärfster Gegner". It was probably his interest in Bordet's work which led him to choose for the subject of his M.D. thesis "The Influence of Electrolytes on Agglutination". The technical ability and experience gained in this work made him a valuable guide and collaborator of his younger colleague, Craigie, in the application of immunological methods to the study of virus disease in which they expanded the earlier work of Mervyn Gordon. They infected rabbits with vaccinia and then used extracts of the crusts developed to immunize other rabbits. They had thus at their disposal immune sera containing antibodies for the virus but devoid of any demonstrable ones for the proteins or other antigens of animal tissues. Such sera were used to get specific precipitates with extracts of crusts due to variola or vaccinia in man but gave none with extracts of crusts due to varicella or other skin lesions. Later it was found that the fixation of complement was a more delicate indicator of the antibody-antigen reaction which occurred in such mixtures. These reactions were later displaced by the cultivation of the infective agent of smallpox on the chick embryo which made the differentiation between variolous and vaccinial lesions possible. They were, however, an important step in the application of immuno. logical methods in the study of virus disease and were published in full by the Medical Research Council ${ }^{1,2}$.

When peculiarly severe epidemics of diphtheria oceurred in the north of England about 1930 and were attributed to a starch fermenting variant of the $C$. diphtheriae described as gravis, Tulloch with characteristic energy and openness to new ideas initiated with the help of Murray a search for bacteria of this type in the eastern midlands of Scotland ${ }^{3-5}$. It was not found to play any significant part at that time, but the predominant bacterium was a finely growing variant, more fastidious in its nutrition, which was designated as intermedius to distinguish it from the gravis and mitis variants described in Leeds. This earlier work brought into relief the change in 1938 when an epidemic of peculiar severity visited Dundee and was found to attack in a surprising degree the children and adults who had undergone prophylactic immunization. The Dundee epidemic strain corresponded closely to the North of England gravis in most respects, but was more fastidious in its nutritive requirements. It was shown later by Chattaway, Happold and their colleague ${ }^{6,7}$ to be nearer to the intermedius strain in requiring pantothenic acid when grown in a medium of known chemical composition. This work of Tulloch and his collaborators in combination with similar observations made by Hartley and a group of collaborators at Gateshead was fully described in an M.R.C. publication in 1950 (ref. 8).

The wide range of Tulloch's knowledge and his masterly assembly and analysis of observations recorded in the literature were never better shown than in his lecture to the Royal College of Physicians of Edinburgh as holder of the Lister Fellowship. This lecture, entitled "Medicine as an Aspect of General Biology", was given in 1956, and as it has not been published a brief indication of its content may not be out of place in this notice.

The thesis developed was that all infectious disease is a manifestation of a balance struck between the host and the invading parasite, but that this balance may exist at various levels. The best illustrations of this were provided by three diseases most studied in South and Central America-coccidioidomycosis, bartonellosis and yellow fever. The importance of different levels of balance between host and parasite is most strikingly illustrated by bartonella infection, which was ultimately shown to be responsible for two conditions long believed to be distinct diseases-Oroya fever, an acute condition with high mortality, in which the balance favours the parasite; and Peruvian wart, a chronic condition with low mortality in which the balance favours the host. Tulloch went on to say that although the identity of the two conditions was all too eonvincingly suggested by Carrion's personal experiment-he infected himself with the juice of a Peruvian wart and died 39 days later of Oroya fever -it was not fully proved until many years later by the work of Noguchi and Battistini published in 1926 .

Tulloch's death has removed from the ranks of those devoted to the study of medicine and microbiology a gifted teacher, an eager enquirer and a most generous colleague and collaborator.

J. W. MCI.EOD

${ }^{1}$ Burgess, W. L., Craigie, J., and Tulloch, W. J., Diagnostic Value of the Vaccinia-Variola Flocculation Reaction, M.R.C. Special Report Series No. 143 (1929)

Craigie, J., and Tulloch, W. J., Further Investigations of the Variola-Vaccinia Floceulation Reaction, M.R.C. Special Report Series No. 156 (1931).

${ }^{3}$ Murray, J. F., J. Path. Bact., 41, 97 (1935).

4 Murray, J. F., Brit. J. Exp. Path., 16, 384 (1935).

'Murray, J. F., Brit. J. Exp. Path., 16, 532 (1935).

Chattaway, F. W., Happold, F. C., Sandford, Mary, Lythgoe, B., and Todd, A. R., Nature, 151, 559 (1943).

Chattaway, F. W., Happold, F. C., and Sandford, Mary, Biochem. J.,

Hartley, P., Tulloch, W. J., and others, The Study of Diphtheria in Troo Areas of Great Britain, M.R.C. Special Report Series No. $272(1950)$.

\section{Prof. I. Mackenzie}

IAN MacKenzie, profossor of surgery and head of the Department of Surgery at Victoria General Hospital, Halifax, Nova Scotia, died in Halifax on October 17 after a long illness at the early age of 56 .

$\mathrm{He}$ was born in Edinburgh and received his medical education at the University of Edinburgh where he graduated in medicine in 1933, and then became an assistant in the department of bacteriology. He held various house appointments at the Edinburgh Royal Infirmary and at the Cumberland Infirmary, Carlisle. In 1939 he was awarded a Commonwealth fellowship for cancer research at the Rockefeller Institute, New York, where he worked under Dr. Peyton Rous.

Returning to Britain at the outbreak of the Sccond World War he served first with the 9 th Lancers and later with the R.A.M.C. in France and the Middle East before being posted for special duties in 1942. He was parachuted into Yugoslavia to serve with Marshall Tito at partisan headquarters and later into occupied France for service with the French resistance movement. For this work he was awarded the Croix de Guerre with gold star and was mentioned in dispatches.

$\mathrm{He}$ returned to the Department of Surgery at the University of Edinburgh in 1946 and later moved to tho Department of Surgery in the University of Durham, and it was in these two surgical departments that he became so interested in what proved to be a life interest in research. In 1957 he was appointed professor of surgery at Dalhousie University, Nova Scotia, and tecame consultant surgeon to the Canadian Forces Hospital, Halifax, and to Camp Hill Hospital (Department of Veterans' Affairs). He was joint author of a Handbook of Surgery. In 1958 he was elected a fellow of the Royal College of Surgeons of Canada, and of the American College of Surgeons in 1960.

He was a great man, both in peace and war, and in the latter his exploits were legendary. Whether it was ranging the Western desert with a surgical unit, or working with the partisans in Yugoslavia or the maquis in France, his qualities as a soldier and his excellence as a surgeon were an example to all.

He created a splendid Department of Surgery at Halifax, where he did a fine job in research, particularly in various aspects of cancer and allied tumours. He was a true Scot, with all the best of that nation's characteristics. As someone said of him at Dalhousie Univorsity, he fulfilled his true role of teacher, research worker and clinical operator of no mean stature. He leaves a widow, two daughters and a son. Walter Mercer 